\title{
THE SELECTIVE RELATION OF CERTAIN VITAL STAINS TO THE TUBERCLE *
}

\author{
PAUL A. LEWIS, M.D. \\ Philladelphia
}

Certain coloring matters are known which, when administered to the living animal, stain portions of its tissues without destroying the life of the animal or that of the affected tissue. The first scientific use of observations of this order is attributed by Fischel $^{1}$ to Misaud (1567), who found that when animals were fed with madder the actively growing portions of the bones were stained red. The long continued researches of Ehrlich on the physiological relationships of the anilin dyes has resulted in many additions to the list of substances exhibiting this form of activity, and it is to be foreseen that much valuable information will in the future be derived from the systematic use of such methods.

Recently Goldman, ${ }^{2}$ in the course of other studies, has applied vital staining methods to a study of tuberculosis as produced by the inoculation of mice. He used isamin-blue for this work. His results, briefly summarized, were, that in the mild disease caused by inoculating mice with avian tubercle bacilli certain wandering cells of the tissues, which have a special affinity for this stain, are very active. In the acute disease caused by the inoculation of virulent bacilli of bovine type, these cells play a much smaller part.

Brown and Evans of Baltimore, in studies so far unpublished, but reported before the American Association of Pathologists and Bacteriologists at Philadelphia, in April, 1912, found that in the rabbit's liver, in the formation of the early tubercle produced by the direct inoculation of this organ, the stellate cells of Kupffer take an active part. The part played by these cells could be most distinctly followed when they were marked out by staining the animal, before inoculation, with trypanblau.

The material at the Phipps Institute has recently afforded us an excellent opportunity to examine by these methods another aspect of the tuberculosis problem. The results have been sufficiently interesting to deserve the following brief description:

*From the Henry Phipps Institute of the University of Pennsylvania.

* Read before the Pathological Society of Philadelphia, June 13, 1912.

1. Fischel: Vital Färbung in Enzyklopüdie d. Mikroskopischen Technik, ed. 2, ii, 590 .

2. Goldman, E. E.: Die äussere und innere Sekretion des gesunden und kranken Organismus im Lichte der Vitalen Färbung. Beiträge zur Klinischen Chirurgie, March, 1912, lxxviii, No. 1. 
When rabbits are inoculated intravenously with a suitable number of tubercle bacilli of human type they survive for months. If such an animal is killed in from two to four months subsequent to inoculation, there are found, very constantly, well-developed tubercles in the lungs and in the kidneys. The lung tubercle is usually located beneath the pleural surface and varies in diameter from 1 to $5 \mathrm{~mm}$. Occasionally larger masses, evidently conglomerations of the smaller, are found. These tubercles in the lungs are largely made up of moderately firm fibrous tissue and are not infrequently caseons at the center. The kidney tubercles are of about the same size, but are less frequently caseous.

Our experiments have made use of such animals and they have been further treated with the dye-stuffs, trypanrot and isaminblau. The following abstracts from the protocols and brief discussion will show the interest attached to the experiments:

I. 1saminblau: Rabbit 371, Feb. 2, 1912, was inoculated intravenously with $.5 \mathrm{mg}$. culture $\mathrm{T} 2.10$ (human type). May 26,1912 , injected intravenously 50 c.e. 1 per cent. isaminblau R. Intraperitoneally 25 c.e. of same. Animal moderately blue at once; increasingly so for several days. June 3, 1912, killed. Autopsy: Scattered tubercles in the lungs and kidneys. The tubercles are stained intensely blue, especially in their outer portions. Microseopic examination of frozen sections shows that the dye appears as granules in large mononuclear cells of the type of endothelial phagocytes. These are found chiefly in the periphery of the tubercular areas. A few are found deep in. Scattered cells of similar type also containing dye-stuff are found along the connective tissue bands of the normal lung tissue. There is in the tubercle a small amount of hyalin substance which takes a very pale blue stain. The tubercles in this animal show very little caseation and this is unstained.

II. Trypanrot.-Rabbit 306, Jan. 9, 1912, was inoculated intravenously with I c.c. of suspension of original material of cervical glands C. (Human type infection.) May 27, 1912, injected subcutaneously 10 c.c. of 1 per cent. trypanrot. May 28, 1912, skin and visible membranes moderately red. June 4, 1912, skin and membranes still red. Animal killed. Autopsy: Few scattered tubercles in lungs. None in any other organ. Some of the smaller tubercles in the lung are stained faintly pink. Most of the smaller ones and all of the larger ones are stained a faint pink in their outer portions and are intensely red in an irregular central portion seen only on section. The lung tissue is unstained. Microscopic examination of frozen sections shows a few scattered mononuclear phagocytic cells in the outer portion of the tubercles containing red granules. Many other such cells contain no stain. The centers of the larger tubercles and those of some of the smaller ones are caseous. The caseous material is stained diffusely and quite intensely red.

The first of these experiments shows again the selective action of isaminblau for the large mononuclear phagocytic cell as pointed out by Goldman. These cells are found abundantly in the peripheral portions of fibroid tubercles.

The second experiment is of great interest, showing, as it does conclusively, that extraneous chemical substances of proper constitution 
may within a few days penetrate to the caseous center of a tuberculous mass and become concentrated there in greater degree than in the normal surrounding tissues. The particular substance used in this experiment, trypanrot, may probably be without effect on the lesion itself, but the result should be a great stimulus to future work in a similar direction. $23 s$ Pine Street. 